\title{
Smoking Family Members In The House As Factor Risk Of Pneumonia Events In Children In Puskesmas Papanggo NorthJakarta, In 2019
}

\author{
Muhammad Hasbye Hasadiki \\ University Respati Indonesia \\ hasbye288@gmail.com
}

\begin{abstract}
The incidence of pneumonia in children under five in the district health center in Papuan, North Jakarta, has increased from 2017-2018 to 156 cases. The purpose of this study was to study and explain smoking as a factor in the incidence of pneumonia in infants. This research is a quantitative study using case control design. The sample consisted of 204 respondents consisting of 68 cases namely toddlers with pneumonia and 136 controls without pneumonia. Analysis of the data used is, univariate, bivariate, chi square, and multivariate using multiple logistic regression. The results of this study showed that most of the toddlers are $<12$ months of age by $35.3 \%$, male sex $51.5 \%$, underweight nutritional status by $85.3 \%$, toddlers with BLB $<2500$ grams by $20.6 \%$, exclusive breastfeeding was not given for $22.1 \%$, measles immunization was never $27.9 \%$, incomplete DPT immunization was $5.9 \%$, maternal knowledge was less than $79.4 \%$, maternal education was low by $57.4 \%$, mothers work by $16.2 \%$, Density of occupancy is not standard $42.6 \%$, have used mosquito repellent $67.6 \%$, there are family members smoking $61.8 \%$, there is a history of asthma of $64.7 \%$, who do not use health insurance by $33.8 \%$.
\end{abstract}

Keywords:, smoking family members, toddlers, factors of incidence of pneumonia, 


\section{BACKGROUND}

Pneumonia is defined as inflammation of the lung parenchyma, which starts from the alveoli to the bronchi or bronchioles, which can be contagious and is characterized by consolidation. Consolidation is a pathological process, when the alveoli are filled with a mixture of inflammatory exudate, bacteria and white blood cells. When irradiated with $\mathrm{x}$-rays will appear blurry shadows that are usually clearly visible in the lungs. Various kinds of organisms can cause pneumonia so it is necessary to apply some type of classification system, at least until the etiology of a particular case is determined. From the DKI Jakarta Profile data in 2017 the number of pneumonia cases in North Jakarta, the total cases were 15,314 cases, $30.04 \%$. Clinically cigarettes are defined as processed products of packaged tobacco, including cigarettes, cigars and in other packaging forms produced from the tobacco plant "Nicotiana Tobacum, Nicotiana Rustica" and other forms containing chemicals such as nicotine, tar and other substances.

Cigarette smoke is very dangerous for health because it has more than 4,000 deadly addictive chemicals such as nicotine, tar, carbon monoxide (CO) which can cause addiction, and increase the risk of dangerous diseases including cancer, COPD, heart disease, impotence, pregnancy disorders, growth disorders. fetus and others. Research data at the Dapartement of Pulmonology and Respiratory Medicine, Faculty of Medicine, Friendship Hospital, shows that the toxic levels of carbon monoxide (CO) in the breath air in people who smoke are higher if done comparison with non-smokers. The level of carbon monoxide (CO) in the breath of a smoker is $22 \mathrm{ppm}$ while a non-smoker is $5.83 \mathrm{ppm}$. While people who are exposed to environmental cigarettes, CO levels in the breath air are 4.68 ppm.

\section{RESEARCH METHOD}

\subsection{Types of Research}

The research method used is an analytic survey. An analytical survey research tries to explore how and why health phenomena occur. Then analyze the dynamics of the correlation between phenomena or between risk factors and effect factors. What is meant by an effect factor is a result of the presence of a risk factor, while a risk factor is a phenomenon that causes an effect to occur. The Case Control Survey Design is an analytical study (survey) that concerns how risk factors are studied using a retrospective approach. In other words, the effect (disease or health status) is identified at this time, then the risk factor is identified as existing or occurring in the past.

\subsection{Location and Exact Research}

This research was conducted at the District Health Center. North Jakarta Papnggo is carried out from June 24 to August 31, 2019.

\subsection{Population and Sample}

The population used in this study was a total of 156 toddlers with a diagnosis of pneumonia at the Papanggo Health Center, North Jakarta within a period of 2 years, 2017-2018. The sample of this research is mostly in the district health center. North Jakarta Papanggo, 
totaling 204 respondents, The samples used in this study consisted of case samples and control samples were:

Case samples with inclusion criteria:

1. Toddler diagnosed with pneumonia

2. Patients with complete medical record data

Control sample with inclusion criteria:

1. Toddlers who go to the health center who do not have pneumonia

2. Toddlers with complete medical record data.

\subsection{Sampling method}

This sampling used a 1:3 case control technique, case 68 while the control 136, so one case two controls.

\subsection{Data Collection}

The data used in this study are secondary data and primary data. Secondary data was obtained from the recapitulation of visits by toddlers with pneumonia at Puseksmas Kec. Papanggo, North Jakarta, while primary data was obtained from interviews using a questionnaire that had been prepared.

\section{Data Analysis Techniques}

\subsection{Univariate Analysis}

Univariate analysis was used in this study to describe the characteristics of each variable studied. All data were analyzed with a significance level of $95 \% \quad(\alpha=0.05)$. Univariate analysis in this study was to see the distribution and percentage of the independent variables, namely, age, gender, nutritional status, low birth weight, history of breastfeeding, history of DPT and measles immunization, mother's education, mother's occupation, mother's knowledge, occupancy density, history of asthma, smoking family members, use of health service facilities.

\section{RESULT}

\subsection{Bivariate Analysis}

In bivariate analysis, the relationship between each variable is described by 2 $x 2$ cross table analysis. This bivariate analysis was conducted to prove the hypothesis by testing the difference in proportions using the chi square statistical test and determining the magnitude of the relationship between the two independent and dependent variables. This cross table analysis used the significance level of of $5 \%(p<0.05)$. If the $p$ value $<0.05$, then the null hypothesis is rejected so that the two variables analyzed have a significant relationship. For cross tables of more than $2 \times 2$ researchers used logistic regression analysis to obtain the OR value by creating a dummy variable.

\subsection{Multivariate Analysis}

The multivariate analysis used in this research is logistic regression test, this is because the dependent variable is in the form of a categorical variable. The logistic regression statistical test used in this study aims to see the relationship of the independent variables including age, gender, birth weight, breastfeeding history, measles immunization status, DPT immunization status nutritional status, history of asthma, mother's education, mother's knowledge, mother's 
Journal Of Ageing And Family (JOAF)

Edition 1, No 1, October 2021

occupation, occupancy density, smoking

habits and health services with the

dependent variable pneumonia which is

categorical using a $95 \%$

http://ejournal.urindo.ac.id/index.php/JournalOfAgeingAndFamily/index 


\subsection{Univariate Analysis}

Table 4.1

Frequency Distribution of Dependent Variables Family members smoke as a risk factor for the incidence of pneumonia in children under five at the Kec. North Jakarta Pappanggo 2018-2019

\begin{tabular}{ccccc}
\hline No. & Variable & Case \% & Control \% & Total \% \\
\hline 1. & Pneumonia & $68(33,3)$ & $136(66,7)$ & $100(100)$
\end{tabular}

Based on table 4.1, it was found that children under five with pneumonia cases were $(33.3 \%)$ and children under five with pneumonia control $(66.7 \%)$.

Table 4.2

Frequency Distribution of Independent Variables Family members smoke as a risk factor for the incidence of pneumonia in children under five at the Kec. North Jakarta Pappanggo 2018-2019.

\begin{tabular}{|c|c|c|c|c|}
\hline No & $\begin{array}{l}\text { Independent } \\
\text { Variable }\end{array}$ & Case $(\%)$ & Control (\%) & Total $(\%)$ \\
\hline \multirow[t]{4}{*}{1.} & Age & & & \\
\hline & $<12$ month & $24(35,3)$ & $34(25,0)$ & $58(28,4)$ \\
\hline & $\geq 12$ month & $44(64,7)$ & $102(75,0)$ & $146(71,6)$ \\
\hline & Total & $68(100,0)$ & $136(100,0)$ & $204(100,0)$ \\
\hline \multirow[t]{4}{*}{2.} & Sex & & & \\
\hline & Male & $35(51,5)$ & $72(52,9)$ & $107(52,5)$ \\
\hline & Female & $33(48,5)$ & $64(47,1)$ & $97(47,5)$ \\
\hline & Total & $68(100,0)$ & $136(100,0)$ & $204(100,0)$ \\
\hline \multirow[t]{4}{*}{3.} & Nutrition & & & \\
\hline & Skinny & $58(85,3)$ & $127(83,4)$ & $185(90,7)$ \\
\hline & Normal & $10(14,7)$ & $9(6,6)$ & $19(9,3)$ \\
\hline & Total & $68(100,0)$ & $136(100,0)$ & $204(100,0)$ \\
\hline
\end{tabular}


Journal Of Ageing And Family (JOAF)

Edition 1, No 1, October 2021

\begin{tabular}{|c|c|c|c|c|}
\hline \multirow[t]{4}{*}{4.} & \multicolumn{4}{|l|}{ Weight } \\
\hline & $<2500$ gram & $14(20,6)$ & $25(18,4)$ & $39(19,1)$ \\
\hline & $\geq 2500$ gram & $54(79,4)$ & $111(81,6)$ & $165(80,9)$ \\
\hline & Total & $68(100,0)$ & $136(100,0)$ & $204(100,0)$ \\
\hline \multirow[t]{5}{*}{5.} & Breastfeeding & & & \\
\hline & History & & & \\
\hline & No Breastfeeding & $15(22,1)$ & $33(24,3)$ & $48(23,5)$ \\
\hline & Breatfeeding & $53(77,9)$ & $103(75,7)$ & $156(76,5)$ \\
\hline & Total & $68(100,0)$ & $136(100,0)$ & $204(100,0)$ \\
\hline \multirow[t]{5}{*}{6.} & Measles & & & \\
\hline & Immunization & & & \\
\hline & No & $19(27,9)$ & $24(17,6)$ & $43(21,1)$ \\
\hline & Yes & $49(72,1)$ & $112(82,4)$ & $161(78,9)$ \\
\hline & Total & $68(100,0)$ & $136(100,0)$ & $204(100,0)$ \\
\hline \multirow[t]{5}{*}{7.} & DPT & & & \\
\hline & Immunization & & & \\
\hline & Incomplete & $4(5,9)$ & $5(3,7)$ & $9(4,4)$ \\
\hline & Complete & $64(94,1)$ & $131(96,3)$ & $195(95,6)$ \\
\hline & Total & $68(100,0)$ & $136(100,0)$ & $204(100,0)$ \\
\hline \multirow[t]{4}{*}{8.} & Mom Knowledge & & & \\
\hline & Low & $54(79,4)$ & $115(86,4)$ & $169(82,8)$ \\
\hline & High & $14(20,6)$ & $21(15,4)$ & $35(17,2)$ \\
\hline & Total & $68(100,0)$ & $136(100,0)$ & $204(100,0)$ \\
\hline \multirow[t]{4}{*}{9.} & Mom Education & & & \\
\hline & Low & $39(57,4)$ & $99(72,8)$ & $138(67,6)$ \\
\hline & High & $29(42,6)$ & $37(27,2)$ & $66(32,4)$ \\
\hline & Total & $68(100,0)$ & $136(100,0)$ & $204(100,0)$ \\
\hline
\end{tabular}

http://ejournal.urindo.ac.id/index.php/JournalOfAgeingAndFamily/index 
Journal Of Ageing And Family (JOAF)

Edition 1, No 1, October 2021

\begin{tabular}{|c|c|c|c|c|}
\hline \multirow[t]{4}{*}{10.} & \multicolumn{4}{|c|}{ Mom Occupation } \\
\hline & Working & $11(16,2)$ & $29(21,3)$ & $40(19,6)$ \\
\hline & Inhouse & $57(83,8)$ & $107(78,7)$ & $164(80,4)$ \\
\hline & Total & $68(100,0)$ & $136(100,0)$ & $204(100,0)$ \\
\hline \multirow[t]{6}{*}{11.} & Urban & & & \\
\hline & Density & & & \\
\hline & Non & $29(42,6)$ & $63(46,3)$ & $92(45,1)$ \\
\hline & Standardized & & & \\
\hline & Standardized & $39(57,4)$ & $73(53,7)$ & $112(54,9)$ \\
\hline & Total & $68(100,0)$ & $136(100,0)$ & $204(100,0)$ \\
\hline \multirow[t]{4}{*}{12.} & Mosquito Re & & & \\
\hline & Yes & $46(67,6)$ & $110(80,9)$ & $156(76.5)$ \\
\hline & No & $22(32,4)$ & $26(19,1)$ & $48(23.5)$ \\
\hline & Total & $68(100,0)$ & $136(100,0)$ & $204(100,0)$ \\
\hline \multirow[t]{5}{*}{13} & Smoking Fa & & & \\
\hline & Behaviour & & & \\
\hline & Yes & $42(61,8)$ & $71(52,2)$ & $113(55,4)$ \\
\hline & No & $26(38,2)$ & $65(47,8)$ & $91(44,6)$ \\
\hline & Total & $68(100,0)$ & $136(100,0)$ & $204(100,0)$ \\
\hline \multirow[t]{4}{*}{14} & Asthma & & & \\
\hline & Yes & $44(64,7)$ & $107(78,7)$ & $151(740)$ \\
\hline & No & $24(35,3)$ & $29(21,3)$ & $41(21,3)$ \\
\hline & Total & $68(100,0)$ & $136(100,0)$ & $204(100,0)$ \\
\hline
\end{tabular}

http://ejournal.urindo.ac.id/index.php/JournalOfAgeingAndFamily/index 


\subsection{Bivariate Analysis}

Table 4.2

Relationship Between Age, Gender, Nutritional Status, Bbblr, History of Breastfeeding, Measles Immunization Status, DPT Immunization Status, Mother's Knowledge, Mother's Education, Mother's Occupation, Occupancy Density, Smoking Family Member Habits, Asthma History, Use of Health Care Services with Pneumonia Incidence in Toddlers at the District Health Center. North Jakarta Papanggo in 2019

\begin{tabular}{|c|c|c|c|c|c|c|c|}
\hline \multirow{3}{*}{ No. } & \multirow{3}{*}{ Variable } & \multicolumn{4}{|c|}{ Pneumonia } & \multirow{3}{*}{ Pvalue } & \multirow[t]{3}{*}{ OR (Cl 95\%) } \\
\hline & & \multicolumn{2}{|c|}{ Case } & \multicolumn{2}{|c|}{ Control } & & \\
\hline & & $\mathbf{N}$ & $\%$ & $\mathbf{N}$ & $\%$ & & \\
\hline \multirow[t]{4}{*}{1.} & Age & & & & & \multirow{4}{*}{0.124} & \\
\hline & $<12$ Month & 24 & 35,3 & 34 & 25,0 & & 1 1.636 (0.871- \\
\hline & $\geq 12$ month & 44 & 64,7 & 102 & 75,0 & & $3.075)$ \\
\hline & Total & 68 & 100,0 & 136 & 100,0 & & \\
\hline \multirow[t]{4}{*}{2.} & Sex & & & & & \multirow{4}{*}{0.843} & \\
\hline & Male & 33 & 48,5 & 64 & 47,1 & & $0.943(0.526-$ \\
\hline & Female & 35 & 51,5 & 72 & 52,9 & & 1.688) \\
\hline & Total & 68 & 100,0 & 136 & 100,0 & & \\
\hline \multirow[t]{4}{*}{3.} & Nutrition & & & & & \multirow{4}{*}{0.061} & \\
\hline & Skinny & 10 & 14,7 & 9 & 6,6 & & $0.411(0.159$ \\
\hline & Normal & 58 & 85,3 & 127 & 93,4 & & - \\
\hline & Total & 68 & 100,0 & 136 & 100,0 & & 1.066) \\
\hline
\end{tabular}


Journal Of Ageing And Family (JOAF)

Edition 1, No 1, October 2021

\begin{tabular}{|c|c|c|c|c|c|c|c|}
\hline \multirow[t]{4}{*}{4.} & Weight & & & & & \multirow{3}{*}{0.706} & \\
\hline & $<2500$ gram & 14 & 20,6 & 25 & 18,4 & & $0.869(0.418$ \\
\hline & $\geq 2500$ & 54 & 79,4 & 111 & 81,6 & & 1.804 \\
\hline & gram Total & 68 & 100,0 & 136 & 100,0 & & \\
\hline
\end{tabular}

\begin{tabular}{|c|c|c|c|c|c|c|c|}
\hline \multirow[t]{9}{*}{5.} & Breastfeedin & & & & & & \\
\hline & g & & & & & & \\
\hline & History & & & & & & \\
\hline & & 15 & 22,1 & 33 & 24,3 & 0.726 & $0.883(0.441-$ \\
\hline & No & & & & & & 1.769) \\
\hline & & 53 & 77,9 & 103 & 75,7 & & \\
\hline & Yes & & & & & & \\
\hline & & 68 & 100,0 & 136 & 100,0 & & \\
\hline & Total & & & & & & \\
\hline 6. & Measles & & & & & & \\
\hline & Immunization & & & & & & \\
\hline
\end{tabular}

\begin{tabular}{|c|c|c|c|c|c|c|c|}
\hline & No & 19 & 27,9 & 24 & 17,6 & 0.089 & $1.810(0.908-$ \\
\hline & Yes & 49 & 72,1 & 112 & 82,4 & & 3.605) \\
\hline & Total & 68 & 100,0 & 136 & 100,0 & & \\
\hline 7. & DPT & & & & & & \\
\hline & Immunization & & & & & & \\
\hline & Incomplete & 4 & 5,9 & 5 & 3,7 & 0.470 & $1.638(0.425-$ \\
\hline & Complete & 64 & 94,1 & 131 & 96,3 & & $6.306)$ \\
\hline & Total & 68 & 100,0 & 136 & 100,0 & & \\
\hline 8. & $\begin{array}{l}\text { Mom } \\
\text { Knowledge }\end{array}$ & & & & & & \\
\hline & ow & 14 & 20,6 & 21 & 15,4 & 0.358 & $1.420(0.671-$ \\
\hline & & 54 & 79,4 & 115 & 54,6 & & 3.004)) \\
\hline & High & 68 & 100,0 & 136 & 100,0 & & \\
\hline & Total & & & & & & \\
\hline 9. & Mom Education & & & & & & \\
\hline & Low & 39 & 57,4 & 99 & 72,8 & 0.026 & $0.503(0.273-$ \\
\hline & High & 29 & 42,6 & 37 & 27,2 & & $0.926)$ \\
\hline & Total & 68 & 100,0 & 136 & 100,0 & & \\
\hline 10 & Mom & & & & & & \\
\hline & Occupation & 11 & 16.2 & 29 & 21,3 & 0.383 & 0.712 (0.331- \\
\hline & Working & 57 & 83,8 & 107 & 78,7 & & $1.530)$ \\
\hline & Inhouse & 68 & 100,0 & 136 & 100,0 & & \\
\hline
\end{tabular}


Journal Of Ageing And Family (JOAF)

Edition 1, No 1, October 2021

\begin{tabular}{|c|c|c|c|c|c|c|c|}
\hline \multirow[t]{6}{*}{11.} & Urban & & & & & \multirow{6}{*}{0.619} & \multirow{6}{*}{$\begin{array}{l}0.862(0.479 \\
1.550)\end{array}$} \\
\hline & Density & & & & & & \\
\hline & No & 29 & 42,6 & 63 & 46,3 & & \\
\hline & & & & & & & \\
\hline & Yes & 39 & 57,4 & 73 & 53,7 & & \\
\hline & Total & 68 & 100,0 & 136 & 100,0 & & \\
\hline \multirow[t]{5}{*}{12.} & Mosquito & & & & & \multirow{5}{*}{0.036} & \\
\hline & Repellent & & & & & & \\
\hline & Yes & 46 & 67,6 & 110 & 80,9 & & 0.491 (0.254- \\
\hline & No & 22 & 32,4 & 26 & 19,1 & & $0.960)$ \\
\hline & Total & 68 & 100,0 & 136 & 100,0 & & \\
\hline \multirow[t]{7}{*}{13.} & Smoking & & & & & \multirow{7}{*}{0.192} & \\
\hline & Family & & & & & & \\
\hline & History & & & & & & \\
\hline & & 24 & 35,3 & 61 & 44,9 & & 0.671 (0.368- \\
\hline & Yes & 44 & 64,7 & 75 & 55,1 & & 1.224) \\
\hline & No & 68 & 100,0 & 136 & 100,0 & & \\
\hline & Total & & & & & & \\
\hline \multirow[t]{5}{*}{14.} & Asthma & & & & & \multirow{5}{*}{0.032} & \\
\hline & Yes & 44 & 64,7 & 107 & 78,7 & & 0.497 (0.261- \\
\hline & $\mathrm{No}$ & 24 & 35,3 & 29 & 21,3 & & $0.947)$ \\
\hline & & 68 & 100,0 & 136 & 100,0 & & \\
\hline & Total & & & & & & \\
\hline \multirow[t]{8}{*}{15.} & Healthcare & & & & & \multirow{8}{*}{0.594} & \multirow{8}{*}{$\begin{array}{l}1.184(0.636- \\
2.205)\end{array}$} \\
\hline & Not & 23 & 33,8 & 41 & 30,1 & & \\
\hline & Utilized & & & & & & \\
\hline & & & & & & & \\
\hline & & 45 & 66,2 & 95 & 69,9 & & \\
\hline & \multirow[t]{2}{*}{ Utilized } & & & & & & \\
\hline & & 68 & 100,0 & 136 & 100,0 & & \\
\hline & Total & & & & & & \\
\hline
\end{tabular}

http://ejournal.urindo.ac.id/index.php/JournalOfAgeingAndFamily/index 
Edition 1, No 1, October 2021

\subsection{Multivariate Analysis}

Table 4.3

Multivariate Analysis Modeling of Smoking as a Risk Factor for Pneumonia Incidence in Toddlers at Puskesmas Kec. North Jakarta Papanggo $(n=204)$

\begin{tabular}{|c|c|c|c|c|c|c|}
\hline \multirow[b]{2}{*}{ No. } & \multirow[b]{2}{*}{ Variable } & \multirow[b]{2}{*}{$P$ value } & \multirow[b]{2}{*}{ OR } & \multicolumn{2}{|c|}{ 95\% Cl EXP (B) } & \multirow[t]{2}{*}{ OR change } \\
\hline & & & & Lower & Upper & \\
\hline \multicolumn{6}{|c|}{ Phase 1} & \\
\hline 1. & Age & 0.668 & 1.270 & 0.510 & 2.858 & \\
\hline 2. & Nutrition & 0.472 & 1.462 & 0516 & 4.142 & \\
\hline 3. & $\begin{array}{l}\text { Measles } \\
\text { Immunization }\end{array}$ & 0.290 & 0.260 & 0.022 & 3.147 & \\
\hline 4. & $\begin{array}{l}\text { Mom } \\
\text { Education }\end{array}$ & 0.343 & 0.620 & 0.231 & 1.664 & \\
\hline 5. & $\begin{array}{l}\text { Mosquito } \\
\text { Repellent }\end{array}$ & 0.237 & 4.420 & 0.376 & 52.025 & \\
\hline \multirow[t]{3}{*}{6.} & Smokin & 0.133 & 0.614 & 0.324 & 1.161 & \\
\hline & $g$ & & & & & \\
\hline & Family & & & & & \\
\hline 7. & Asthma & 0.081 & 2.112 & 0.913 & 4.887 & \\
\hline
\end{tabular}

\begin{tabular}{|c|c|c|c|c|c|c|}
\hline & Final Phas & & & & & \\
\hline 1. & $\begin{array}{l}\text { Mosquito } \\
\text { Repellent }\end{array}$ & 0.017 & 2.306 & 1.160 & 4.585 & $0,4 \%$ \\
\hline 2. & $\begin{array}{l}\text { Smoking } \\
\text { Family }\end{array}$ & 0.128 & 0.619 & 0.334 & 1.148 & $-0,8 \%$ \\
\hline 3. & Asthma & 0.045 & 2.334 & 1.021 & 5.333 & $-10 \%$ \\
\hline
\end{tabular}

http://ejournal.urindo.ac.id/index.php/JournalOfAgeingAndFamily/index 


\section{DISCUSSION}

2.1 Relationship of Age with the incidence of pneumonia in children under five

In the results of this study, there was no significant difference or relationship between age status and the incidence of pneumonia in children under five at the Kec. Papanggo, North Jakarta, obtained a $\mathrm{p}$ value $=0.124$ and an $\mathrm{OR}$ value of 1.636 (95\% Cl: 0.871-3.075), meaning that ages $<12$ months have a risk of toddler suffering from pneumonia 1.6 times greater than toddlers born 12 months. The results of this study are in line with research (Adawiyah \& Duarsa, 2016). In this study, there was no significant relationship between age $<12$ months and the incidence of pneumonia in children under five with $P$ value $=$ 0.831 . The results of this study indicate that the number of respondents under five years of age $<12$ months is less than that of children aged $>12$ months, but the age factor is the dominant factor in the incidence of pneumonia in children under five. Seeing this condition, it is very important to maintain the health of children aged $<12$ months by paying attention to proper nutrition and providing immunizations to prevent children from getting infected. Infants are more susceptible to pneumonia than toddlers. Children aged less than 1 year have a cough and cold $30 \%$ greater than the group of children aged between 2 to 3 years. It's easy for those under 1 year to get at risk pneumonia, caused by immature immunity and relatively narrow airways. From research in Indramayu in 1993, it was concluded that the older the baby or toddler who was suffering from pneumonia, the lower the risk of dying from pneumonia (Rizanda, 2006). Infants and toddlers have lower body defense mechanisms than adults, so toddlers fall into a group that is prone to infections such as influenza and pneumonia. toddlers aged 0-24 months are more susceptible to pneumonia than children aged over 2 years. This is due to immature immunity and relatively narrow respiratory tract (DepKes RI, 2004).

\subsection{Relationship} between sex and the incidence of pneumonia in children under five

In the results of this study there was no significant difference or relationship between gender status and the incidence of pneumonia in children under five at the Kec. Papanggo, North Jakarta, obtained a $p$ value $=0.843$ and an $O R$ value of $0.943(95 \% \mathrm{Cl}: 0.526$ 1.688) meaning that toddlers with male gender have a risk of toddlers suffering from pneumonia 0.9 times greater than toddlers with female sex. The results of this study are in line with research (Husein, 2016). In this study, there was no significant relationship between male sex and the incidence of pneumonia in toddlers with $p$ value $=0.685$ and $\mathrm{OR}=1.04$, meaning that the male gender had a risk of pneumonia 1 times greater than that of the under-five gender. female.. From a research in Indramayu that was conducted for 1.5 years, it was concluded that pneumonia affects more boys (52.9\%) than girls (Sutrisna, 1993). This is also in accordance with the theory put forward by the Ministry of Health of the Republic of Indonesia which states that men are one of the risk factors for pneumonia incidence in children under five. Several studies have found a number of studies found a number of 
respiratory tract diseases of the respiratory tract which are influenced by the presence of physical differences in the anatomy of the airways. with girls. This can increase the frequency of respiratory tract diseases.

\subsection{Relationship of Nutritional} Status with the incidence of pneumonia in children under five In the results of this study there is no significant difference or relationship between nutritional status and the incidence of pneumonia in children under five at the district health center. Papanggo, North Jakarta, the $\mathrm{p}$ value $=0.061$ and the $\mathrm{OR}$ value of 0.411

(95\% CI : $0.159-1.066)$ means

Underweight nutritional status has a risk of under-five children suffering from pneumonia 0.4 times greater than normal nutritional status. The results of this study are in line with research (Mardani, Pradigdo, \& Mawarni, 2018). There was no relationship between nutritional status and the incidence of pneumonia in children aged 0-59 months $(\mathrm{p}=0.176)$, and malnutrition was not a risk factor for the incidence of pneumonia in children aged 0-59 months in the Gombong II Health Center Work Area. Based on the results of research on the nutritional status of underweight toddlers, $14.7 \%$, one of which can be caused by insufficient food intake, the thing that plays an important role here is parents in paying attention to their children's intake. And parents do not know about good nutrition knowledge and are able to arrange good menus for their toddlers to consume. The more nutritional knowledge a person has, the more he will take into account the type and amount of food he gets for consumption. The condition of the body with thin nutrition, will cause a child to be susceptible to disease. Bacteria or viruses easily enter the body of individuals with low body resistance or immunity. Malnutrition can weaken the immune system and in children with the condition

This can weaken the respiratory muscles so that toddlers with less nutrition will be more susceptible to pneumonia than toddlers with normal nutrition. Several studies reported that malnutrition will reduce the immune capacity to respond to pneumonia infection including impaired granulocyte function, decreased complement function, and also cause micronutrient deficiencies (Sunyataningkamto, 2004). Nutritional status is one indicator of children's health and welfare. The problem of the nutritional status of children under five is malnutrition. Toddlers with poor nutritional status will be more susceptible to pneumonia compared to normal nutrition because of the lack of immune factors. Infectious diseases themselves will cause toddlers to have no appetite and lead to malnutrition. In a state of malnutrition, toddlers are more susceptible to pneumonia and even longer attacks.

1.4 Relationship of weight with the incidence of pneumonia in children under five

In the results of this study there was no significant difference or relationship between LBW status and the incidence of pneumonia in children under five at the Kec. Papanggo, North Jakarta. Obtained $p$ value $=0.706$ and $O R$ value of 0.869 (95\% CI : 0.418 1.804) means bblr <2500 grams 
have a risk of toddlers suffering from pneumonia 0.8 times greater than toddlers born 2500 grams.

The results of this study are in line with research (Efni et al., 2016). In this study, there was no significant relationship between a history of low birth weight and the incidence of pneumonia in children under five with $p$ value $=0.552 \mathrm{OR}=0.537$ and this study is in line with research (Regina et al, 2013) in Semarang that there was a non-significant relationship between low birth weight infants and children with low birth weight. the incidence of pneumonia in children under five ( $p$ $=0.191$ ). Based on the results of this study, it was found that a history of low birth weight was not a risk factor for pneumonia. This is because the majority of cases and controls $( \pm 80 \%)$ had no history of low birth weight, so there was no significant relationship between a history of low birth weight and the incidence of pneumonia because toddlers with low birth weight formed antiimmune substances. still not perfect, the growth and maturation of organs and organs of the body is not perfect as a result, babies with low birth weight are easier to get complications and infections, especially pneumonia and other respiratory diseases. Babies with low birth weight (LBW) have a greater risk of death than babies with normal birth weight. This especially occurs in the first months of birth as a result of the formation of anti-immune substances that are less than perfect so that more susceptible to infectious diseases, especially pneumonia and other respiratory tract diseases (WHO, 1986).

1.5 Relationship of history of exclusive breastfeeding with the incidence of pneumonia in children under five

In the results of this study, there was no significant difference or relationship between a history of exclusive breastfeeding and the incidence of pneumonia in children under five at the Kec. Papanggo, North Jakarta, the p value $=0.726$ OR $0.883(95 \% \mathrm{CI}$ : 0.441-1.769) means

not given exclusive breastfeeding has a risk of toddler suffering from pneumonia 0.8 times greater than being given exclusive breastfeeding. The results of this study are in line with research (Efni et al., 2016). In this study, there was no significant relationship between a history of exclusive breastfeeding and the incidence of pneumonia in children under five with $\mathrm{p}$ value $=$ 1.257 OR $=0.735(95 \%$ CI: $0.333-4.748$ )

A history of exclusive breastfeeding not given has a risk of under-five children suffering from pneumonia 0.7 times greater than being given exclusive breastfeeding. Based on the results of the interviews, there were various reasons put forward by mothers so that they did not give exclusive breastfeeding to their children, one of which said that breast milk did not come out much so that mothers gave formula milk to their toddlers. Several epidemiological studies suggest that breast milk protects infants and children.

One of the infectious diseases is pneumonia because the nutrients contained in breast milk guarantee the nutritional status of infants so that the morbidity and mortality rates in infants decrease. Breast milk is known to have unique anti-infective properties. Breast 
milk also provides passive protection for toddlers' bodies against pathogens that enter the body. Types of passive protection in the form of anti-bacterial and anti-viral which can inhibit colonization by gramnegative species. Exclusive breastfeeding, especially in the first month of a baby's life, can reduce the incidence and severity of infectious diseases. Breastfeeding can provide immunity against various diseases, especially pneumonia because breast milk contains immune substances that can protect itself from various infectious diseases, bacteria, viruses, fungi and parasites (Nugroho, 2011). Mother's Milk (ASI) is a natural drink for newborns at the beginning of life that has many benefits during growth. The composition of breast milk is very appropriate to meet the nutritional needs that increase according to the baby's age (Lebuan \& Somin, 2017).

\subsection{The relationship between} measles immunization and the incidence of pneumonia in children under five.

In the results of this study, there was no significant difference or relationship between measles immunization and the incidence of pneumonia in children under five at the Kec.

Papanggo, North Jakarta. The $\mathrm{p}$ value $=0.089$ and the $\mathrm{OR}$ value of $1.810 \quad$ (95\% CI: $0.908 \quad-3,605)$ means that measles immunization has never had a risk of under-five children suffering from pneumonia 1.8 times greater than those who have had measles immunization. The results of this study are in line with research (Efni et al., 2016) which shows that there is no significant relationship between the measles immunization status of children under five with the incidence of pneumonia. This indicates that measles immunization status has an effect on the incidence of pneumonia in children under five. The results of the statistical test OR 0.553 (95\% CI: 0.2771.101) explained that infants with measles immunization status who had never had a chance of experiencing pneumonia were 0.5 times higher than those who had measles immunization. Based on the results of the interview, the researcher obtained a $\mathrm{p}$ value of 0.089 so that it can be concluded that there is no significant relationship between measles immunization status and the incidence of pneumonia in children under five at the Papanggo District Health Center, North Jakarta. The OR value of 1.810 means that measles immunization status has never had a risk of under-five children suffering from pneumonia 1.8 times compared to measles immunization status. Because from the results of the study the immunization coverage at the Papanggo district health center was quite high $72.1 \%$, although there were still cases of pneumonia found in toddlers. Fantahun (2007) in his research in Tanzania found that low immunization coverage was

http://ejournal.urindo.ac.id/index.php/JournalOfAgeingAndFamily/index 
associated with child mortality. Based on the results of the study, of the respondents who knew the basic immunization status of their toddlers, only $36.8 \%$ of toddlers received complete basic immunizations. This is certainly very low compared to indicators of achievement of Universal Child Immunization (UCI) in accordance with Kepmenkes Number 482/MENKES/SK/IV/2010

regarding the Universal Child Immunization National Immunization Acceleration Movement 2010-2014 (GAIN UCI 2010-2014), namely the basic immunization coverage for toddlers was $85 \%$ in 2012 and $90 \%$ in 2014 . Many factors affect this low immunization coverage, among others, allegedly due to This is due to a lack of public knowledge about the importance of immunization, low access to health services, and immunization dropout rates (Kemenkes, 2010).

\section{Conclusion}

Based on the results and discussion of the research on "Smoking as a risk factor for the incidence of pneumonia in toddlers at the Papanggo District Health Center, North Jakarta in 2019" the researchers concluded that:

1. The use of mosquito repellent has been proven to have a dominant and influential effect on

increased incidence of pneumonia in children under five

district health center. Papanggo, North Jakarta.

2. Factors that are significantly or dominantly related to the incidence of pneumonia in children under five at the
Puskesmas Papanggo sub-district, North Jakarta, namely, the use of mosquito coils, while the counfunding variables are family members smoking and a history of asthma.

3. Factors that are not related to The increasing incidence of pneumonia in children under five at the Papanggo Public Health Center, North Jakarta, namely, age, gender, nutritional status, low birth weight, history of exclusive breastfeeding, measles immunization status, DPT immunization status, mother's knowledge, mother's education, mother's occupation, density of occupancy, use of health services.

\subsection{Suggestions}

1. Educational Institution

It is hoped that the University of Respati Indonesia will use the results of this study as a reference related to research on the incidence of pneumonia in children under five and it is also hoped that this research will develop with a cohort design, larger sample size, and more research locations.

amount to get the variation of the dominant factor.

\section{Health Center}

It is hoped that health workers will increase health education to the public regarding the dangers of using mosquito repellent in the long term. Informing the public that it is better to pay attention to the following things in using mosquito repellent, namely, Knowing the effects and dangers of the mosquito repellent they use, seeking information about the mosquito repellent used and the correct way to use the mosquito repellent, using the mosquito repellent in an appropriate way. properly and correctly, so as to achieve the expected effect of the insect repellent and do not pose a danger to those who use it, choose the correct and appropriate mosquito repellent according to the use of each type of mosquito 
repellent.

\section{Health Government Institutions}

The government should pay attention to efforts to prevent vector-borne diseases by taking into account the following:

the following: The government can produce mosquito repellent that is effective/effective and safe and inexpensive. The government supervises the dangers of using insect repellent by monitoring the level of mosquito repellent resistance and monitoring the side effects of mosquito repellent.

\section{Bibliography}

1. Adawiyah, R., \& Duarsa,

A. (2016). Faktor-faktor

Yang Berpengaruh

Terhadap Kejadian

Pneumonia Pada Balita di

Puskesmas Susunan Kota

Bandar Lampung Tahun

2012. Jurnal Kedokteran

Yarsi, 24(1), 51-68.

2. Aisma Miridhia Husnita. (2018).

Digital Digital Repository

Repository Universitas Universitas

Jember Jember Digital Digital

Repository Repository Universitas

Universitas Jember

3. Annissa, R. (2009). Faktor-faktor Yang

Berhubungan Dengan Kejadian

Pneumonia pada Balita 10-59 bulan

yang Dirawat Inap di RSUP

Persahabatan Jakarta.

Journal, 6-26.

4. Anwar, A., \& Dharmayanti, I. (2014). Artikel Penelitian 359. Pneumonia Among Children Under Five Years of Age in Indonesia, 8(8), 359-365. https://doi.org/10.1016/S0 090-4295(00)00847-5

5. Ariawan, I. (n.d.). Besar dan metode sampel pada penelitian kesehatan, Jurusan Biostatistik

dan Kependudukan Fakultas

Kesehatan,

Universitas

Indonesia.

6. Depkes DKI Jakarta. (2017).

Profil Kesehatan DKI

JAKARTA Tahun 2017, (4),

156. Retrieved from

https://dinkes.jakarta.go.i

d/wp/2018/09/PROFIL- KES-

DKI-JAARTA- TAHUN-

2017.pdf

7. Depkes RI 2009. (2013). Jurnal Umur, Pengertian Awal, Lansia Akhir, Lansia, (April), 55-56

8. Dewi, A., \& Wuryaningsih, C. E. (2013). Wilayah Kerja Puskesmas Pancoran Mas Depok Tahun 2013, 1-16.

9. Dewiningsih, U. (2018). Faktor Lingkungan dan Perilaku Kejadian Pneumonia Balita Usia 12-59 Bulan. HIGEIA (Journal of Public Health Research and Development), 2(3), 453- 464. https://doi.org/10.15294/

HIGEIA.V2I3.23512

http://ejournal.urindo.ac.id/index.php/JournalOfAgeingAndFamily/index 
10. Efni, Y., Machmud, R., \&Pertiwi, D. (2016). Faktor Risiko yang Berhubungan dengan Kejadian Pneumonia pada Balita di Kelurahan Air Tawar Barat Padang. Jurnal Kesehatan Andalas, 5(2),365-370. Retrieved from http://jurnal.fk.unand.ac.id

11. Gayatri, D. septi pratiwi moch. yunu. rara warih. (2017). Hubungan Antra Faktor Perilaku Orang Tua Dengan Kejadian Pneumonia Balita Di Wilayah Kerja Puskesmas Dinoyo Kota Malang, 1- 13.

12. Hartati, S., Nurhaeni, N., \& Gayatri, D. (2012). Faktor risiko terjadinya pneumonia pada anak balita. Journal Keperawatan Kesehatan, 15(1), 1320.

13. Hayati, S., \& Keperawatan, F. I. (2014). Jurnal 29, (1), 62-67.

14. Husein, R. (2016).Universitas Indonesia Universitas Indonesia Depok, (1606970695),85-93.

15. Kemenkes RI (2010). (n.d.). Status, Mengukur Dengan, Gizi Massa, Indeks, 2.

16. Kementrian Kesehatan RI. (2016). Direktorat Pencegahan dan Pengendalian Penyakit.
17. Kepmenkes RI

No.829/Menkes/SK/VII/1 999.

(1999). Kepmenkes RI

No.829/Menkes/SK/VII/1 999,

(829). https://doi.org/10.1007/s1 3398-014-0173-7.2

18. Maramis, P., Ismanto, A. Y., \& Babakal, A. (2013). Hubungan Tingkat Pendidikan Dan Pengetahuan Ibu Tentang pneumonia Dengan Kemampuan Ibu Merawat Balita Ispa Pada Balita Di Puskesmas Bahu Kota Manado. Jurnal Keperawatan UNSRAT, 1(1). 